\title{
FilmArray $^{\mathrm{TM}} \mathrm{Gl}$ panel performance for the diagnosis of acute gastroenteritis or hemorragic diarrhea
}

\author{
Antonio Piralla', Giovanna Lunghi², Gianluigi Ardissino³, Alessia Girello', Marta Premoli', Erika Bava', \\ Milena Arghittu², Maria Rosaria Colombo², Alessandra Cognetto ${ }^{2}$, Patrizia Bono ${ }^{2}$, Giulia Campanini ${ }^{1}$, \\ Piero Marone ${ }^{1}$ and Fausto Baldanti ${ }^{1,4^{*}}$
}

\begin{abstract}
Background: Acute gastroenteritis is a common cause of morbidity and mortality in humans worldwide. The rapid and specific identification of infectious agents is crucial for correct patient management. However, diagnosis of acute gastroenteritis is usually performed with diagnostic panels that include only a few pathogens. In the present bicentric study, the diagnostic value of FilmArray ${ }^{\mathrm{TM}} \mathrm{Gl}$ panels was assessed in unformed stool samples of patients with acute gastroenteritis and in a series of samples collected from pediatric patients with heamorragic diarrhea. The clinical performance of the FilmArray ${ }^{\mathrm{TM}}$ gastrointestinal (Gl) panel was assessed in 168 stool samples collected from patients with either acute gastroenteritis or hemorragic diarrhea. Samples showing discordant results between FilmArray and routine methods were further analyzed with an additional assay.

Results: Overall, the FilmArray ${ }^{\mathrm{TM}} \mathrm{Gl}$ panel detected at least one potential pathogen in 92/168 (54.8\%) specimens. In 66/92 (71.8\%) samples, only one pathogen was detected, while in 26/92 (28.2\%) multiple pathogens were detected. The most frequent pathogens were rotavirus 13.9\% (22/168), Campylobacter 10.7\% (18/168), Clostridium difficile 9.5\% $(16 / 168)$, and norovirus $8.9 \%$ (15/168). Clostridium difficile was identified only in patients with acute gastroenteritis $(p<0.01)$, while STEC was detected exclusively in patients with hemorragic diarrhea $(p<0.01)$. In addition, Campylobacter spp., Salmonella spp., EPEC and E. coli producing Shiga-like toxin were more frequently detected in patients with hemorragic diarrhea $(p<0.05)$. The overall percent agreement calculated in samples was $73.8 \%$ and $65.5 \%$, while $34.5 \%$ were discordant. After additional confirmatory analyses, the proportion of discordant samples decreased to $7.7 \%$. Rotavirus and astrovirus were the most frequently unconfirmed pathogens.
\end{abstract}

Conclusion: In conclusion, the FilmArray ${ }^{\mathrm{TM}} \mathrm{Gl}$ panel has proved to be a valuable new diagnostic tool for improving the diagnostic efficiency of $\mathrm{Gl}$ pathogens.

Keywords: Acute gastroenteritis, FilmArray ${ }^{\mathrm{TM}}$, Hemorragic diarrhea, Multiplex PCR

\section{Background}

Acute gastroenteritis (AGE) is a common cause of morbidity and mortality in humans worldwide [1]. The majority of cases occur in developing countries with poor hygiene standards and water sanitation problems. Acute gastroenteritis is the most severe and most

\footnotetext{
* Correspondence: f.baldanti@smatteo.pv.it; fausto.baldanti@unipv.it ${ }^{1}$ Microbiology and Virology Department, Fondazione IRCCS Policlinico San Matteo, Pavia, Italy

${ }^{4}$ Section of Microbiology, Department of Clinical, Surgical, Diagnostic and Pediatric Sciences, University of Pavia, Pavia, Italy

Full list of author information is available at the end of the article
}

common cause of diarrhea in children under 5 years of age [1]. Infectious gastrointestinal illness is a clinical syndrome whose aetiology is as varied as its presentation. Symptoms range from mild or self-limiting diarrhea to potentially life-threatening hemolytic uremic syndrome or pseudomembranous colitis. A wide range of pathogens cause acute gastroenteritis including viruses: norovirus, rotavirus and adenovirus [1], bacteria: Campylobacter, Salmonella, Shigella, Escherichia, and Yersinia species [2, 3], and parasites: Entamoeba hystolytica, Giardia, and Cryptosporidium [4]. 
Hemolytic uremic syndrome (HUS) is the most common cause of pediatric acute kidney damage and is one of the most serious acute pediatric diseases with a fatality rate of $3 \%$ to $5 \%$ [5]. The disease, however, is not limited to children, as shown during an outbreak of Shiga toxin (Stx)-producing Escherichia coli (STEC) infection in Germany in 2011, which caused $>800$ adult cases [6]. In nearly $85 \%$ of cases, HUS develops as a complication of STEC intestinal infection with hemorragic diarrhea [7]. Diagnosis of STEC-HUS is currently based on the detection of Shiga toxins (Stx S) and/or isolation of STEC in stools.

The rapid and specific identification of infectious agents is crucial for appropriate patient management. In addition, surveillance of new cases is needed for outbreak prevention and control especially in close-contact communities such as hospitals and long-term care facilities. Unfortunately, the number of agents involved in gastrointestinal infections makes the construction of comprehensive diagnostic panels challenging. In fact, the diagnosis of acute gastroenteritis is usually either performed with diagnostic panels that include only a few pathogens or with diagnostic assays with limited performance $[8,9]$. To overcome the difficulties in conventional gastroenteritis related diagnostics, a trend in recent years has been the introduction of molecular multiplex assays to replace and/or complement traditional microbiological tests [10-12]. The added value of molecular detection for enteropathogens in comparison with conventional methods has been demonstrated [13-16]. In this diagnostic context, the FilmArray ${ }^{\text {max }}$ technology (BioFire Diagnostics, Salt Lake City, Utah) has recently improved rapid PCR multiplexing. The FilmArray ${ }^{\text {Tm }}$ gastrointestinal (GI) panel was designed to simultaneously detect 22 of the most common gastrointestinal pathogens. The FilmArray GI panel offers high sensitivity and specificity $[14,17,18]$ and has been recently used as point-ofcare according to the syndromic approach [19].

In the present bicentric study, the diagnostic value of FilmArray $^{\text {Tim }}$ GI panels was assessed in unformed stool samples of patients with AGE and in a series of samples collected from pediatric patients with heamorragic diarrhea.

\section{Methods}

\section{Study population and samples}

Unformed stool samples were retrospectively collected from patients with AGE from December 2014 through May 2015. The stool samples were stored at $-80{ }^{\circ} \mathrm{C}$ and analyzed in June 2015 at the Microbiology and Virology Department, Fondazione IRCCS Policlinico San Matteo, Pavia (laboratory A) and Fondazione Cà Granda Ospedale Maggiore Policlinico, Milano (laboratory B). The latter is also a reference center for HUS control, prevention and management. Inclusion criteria were: i) hospitalization of patients with AGE; ii) hemorragic diarrhea in pediatric patients and iii) the availability of stool samples at GI syndrome onset. Exclusion criteria were: i) the presence of chronic diarrhea; ii) immunodeficiency of patients (transplant recipients and/or those undergoing chemotherapy); and iii) repeated samples.

This study was approved by the Institutional Review Board (IRB) of both centres. Informed consent was not required and samples were anonymized, only retaining gender, age and the category of clinical syndromes (acute gastroenteritis or hemorragic diarrhea) according to guidelines on the use of residual biological specimens for scientific purposes in keeping with Italian law (art.13 D.Lgs 196/2003).

\section{FilmArray $^{\mathrm{TM}} \mathrm{Gl}$ panel}

The following agents are included in the FilmArray ${ }^{\mathrm{mm}}$ GI panel (BioFire Diagnostics, Salt Lake City, UT): Campylobacter (jejuni, coli, and upsaliensis), C. difficile (Toxin A/ B), Plesiomonas shigelloides, Salmonella, Yersinia enterocolitica, Vibrio (parahaemolyticus, vulnificus, and cholerae), Vibrio cholera, enteroaggregative E. coli (EAEC), enteropathogenic E. coli (EPEC), enterotoxigenic E. coli (ETEC), Shiga-like toxin-producing E. coli (STEC), E. coli O157, Shigella/enteroinvasive E. coli (EIEC), Cryptosporidium spp., Cyclospora cayetanensis, Entamoeba histolytica, Giardia lamblia, adenovirus (AdV) F40/41, astrovirus, norovirus GI/GII, rotavirus A, and sapovirus (I, II, IV, and V).

The FilmArray ${ }^{\text {Tw }}$ GI pouch system contains dried reagents for all the steps needed for extraction, PCR amplification and detection of the pathogens listed above. The pouch was rehydrated under negative pressure using the hydration injection vial. The correct volume of liquid was introduced into the pouch with a vacuum. Testing on the FilmArray ${ }^{\mathrm{mm}}$ platform (version 1.7) was performed according to the manufacturer's instructions using $200 \mu \mathrm{l}$ of stool re-suspended in Cary-Blair transport medium, which is the sample volume recommended by the manufacturer. Samples were diluted in sample buffer in the sample injection vial. The cannula of the sample injection vial was inserted into the pouch port and a pre-established volume of liquid was drawn into the pouch by vacuum. Results were available approximately 1 hour after placing the pouch in the FilmArray $^{\text {mat }}$ Instrument.

\section{Standard methods}

At laboratory A, the stool samples were routinely tested for bacterial and parasitological pathogens using a combination of culture, immunochromatographic and molecular assays (Table 1). For virus detection, a panel of real-time RT-PCR or PCR detecting norovirus, astrovirus, 
Table 1 Methods routinely used in the two centers and additional assay used to confirm FilmArray Gl results

\begin{tabular}{|c|c|c|c|c|}
\hline \multirow[t]{3}{*}{ Pathogen } & \multicolumn{4}{|l|}{ Methods } \\
\hline & \multicolumn{2}{|l|}{ Laboratory $A^{a}$} & \multicolumn{2}{|l|}{ Laboratory $\mathrm{B}^{\mathrm{b}}$} \\
\hline & In use & $\begin{array}{l}\text { Analysis of } \\
\text { discrepant results }\end{array}$ & In use & $\begin{array}{l}\text { Analysis of } \\
\text { discrepant results }\end{array}$ \\
\hline Clostridium difficile & immunochromatographic test & $\begin{array}{l}\text { Xpert }{ }^{\circ} \text { C. difficile/Epi } \\
\text { (real-time PCR) }\end{array}$ & Allplex ${ }^{\mathrm{TM}} \mathrm{Gl}$ assay & $\begin{array}{l}\text { Xpert }{ }^{\circ} \text { C. difficile/Epi } \\
\text { (real-time PCR) }\end{array}$ \\
\hline Plesiomonas shigelloides & none & none & Allplex ${ }^{\mathrm{TM}} \mathrm{Gl}$ assay & none \\
\hline Salmonella spp & direct plating - culture & $\begin{array}{l}\text { BD MAX }{ }^{T M} \text { Enteric } \\
\text { Bacterial Panel }\end{array}$ & Allplex ${ }^{\mathrm{TM}} \mathrm{Gl}$ assay & $\begin{array}{l}\mathrm{BD} \mathrm{MAX}^{\mathrm{TM}} \text { Enteric } \\
\text { Bacterial Panel }\end{array}$ \\
\hline Yersinia enterocolitica & direct plating - culture & none & Allplex ${ }^{\mathrm{TM}} \mathrm{Gl}$ assay & none \\
\hline $\begin{array}{l}\text { Campylobacter spp. (jejuni, } \\
\text { coli and upsaliensis) }\end{array}$ & direct plating - culture & $\begin{array}{l}\text { BD MAX }{ }^{\mathrm{TM}} \text { Enteric } \\
\text { Bacterial Panel }\end{array}$ & Allplex ${ }^{\mathrm{TM}} \mathrm{Gl}$ assay & $\begin{array}{l}\mathrm{BD} \mathrm{MAX}^{\mathrm{TM}} \text { Enteric } \\
\text { Bacterial Panel }\end{array}$ \\
\hline Vibrio spp. and V. cholerae & direct plating - culture & none & Allplex ${ }^{\mathrm{TM}} \mathrm{Gl}$ assay & none \\
\hline $\begin{array}{l}\text { Enteroaggregative E. coli } \\
\text { (EAEC) }\end{array}$ & direct plating - culture & none & Allplex ${ }^{\mathrm{TM}} \mathrm{Gl}$ assay & none \\
\hline $\begin{array}{l}\text { Enteropathogenic E. coli } \\
\text { (EPEC) }\end{array}$ & direct plating - culture & none & Allplex ${ }^{\mathrm{TM}} \mathrm{Gl}$ assay & none \\
\hline $\begin{array}{l}\text { Enterotoxigenic E. coli } \\
\text { (ETEC) }\end{array}$ & direct plating - culture & none & Allplex ${ }^{\mathrm{TM}} \mathrm{Gl}$ assay & none \\
\hline E.coli 0157 & agglutination test & none & Allplex ${ }^{\mathrm{TM}} \mathrm{Gl}$ assay & none \\
\hline $\begin{array}{l}\text { Shiga-like toxin producing } \\
\text { E.coli (STEC) }\end{array}$ & $\begin{array}{l}\text { direct plating culture/ } \\
\text { immunochromatographic test }\end{array}$ & $\begin{array}{l}\text { BD MAX }{ }^{\mathrm{TM}} \text { Enteric } \\
\text { Bacterial Panel }\end{array}$ & Allplex ${ }^{\mathrm{TM}} \mathrm{Gl}$ assay & $\begin{array}{l}\mathrm{BD} \mathrm{MAX}^{\mathrm{TM}} \text { Enteric } \\
\text { Bacterial Panel }\end{array}$ \\
\hline $\begin{array}{l}\text { Shigella/Enteroinvasive } E \text {. } \\
\text { coli (EIEC) }\end{array}$ & direct plating - culture & $\begin{array}{l}\text { BD MAX'M Enteric } \\
\text { Bacterial Panel }\end{array}$ & Allplex ${ }^{\mathrm{TM}} \mathrm{Gl}$ assay & $\begin{array}{l}\mathrm{BD} \mathrm{MAX}^{\mathrm{TM}} \text { Enteric } \\
\text { Bacterial Panel }\end{array}$ \\
\hline Cryptosporidium & $\begin{array}{l}\text { direct microscopy/ } \\
\text { immunochromatographic test }\end{array}$ & Allplex ${ }^{\mathrm{TM}} \mathrm{Gl}$ assay & $\begin{array}{l}\text { direct microscopy/ } \\
\text { immunochromatographic test }\end{array}$ & Allplex ${ }^{\mathrm{TM}} \mathrm{Gl}$ assay \\
\hline Entameba histolytica & $\begin{array}{l}\text { direct microscopy/ } \\
\text { immunochromatographic test }\end{array}$ & Allplex ${ }^{\mathrm{TM}} \mathrm{Gl}$ assay & $\begin{array}{l}\text { direct microscopy/ } \\
\text { immunochromatographic test }\end{array}$ & Allplex ${ }^{\mathrm{TM}} \mathrm{Gl}$ assay \\
\hline Cyclospora cayetanensis & $\begin{array}{l}\text { direct microscopy/ } \\
\text { immunochromatographic test }\end{array}$ & Allplex ${ }^{T M} \mathrm{Gl}$ assay & $\begin{array}{l}\text { direct microscopy/ } \\
\text { immunochromatographic test }\end{array}$ & Allplex ${ }^{\mathrm{TM}} \mathrm{Gl}$ assay \\
\hline Giardia lamblia & $\begin{array}{l}\text { direct microscopy/ } \\
\text { immunochromatographic test }\end{array}$ & Allplex ${ }^{\mathrm{TM}} \mathrm{Gl}$ assay & $\begin{array}{l}\text { direct microscopy/ } \\
\text { immunochromatographic test }\end{array}$ & Allplex ${ }^{T M} \mathrm{Gl}$ assay \\
\hline Adenovirus, & real-time PCR (all AdV strains) & PCR/sequencing & FTD & $\mathrm{PCR} /$ sequencing \\
\hline Rotavirus $A, B$ & immunochromatographic test & real-time RT-PCR & FTD & Allplex ${ }^{\mathrm{TM}} \mathrm{Gl}$ assay \\
\hline Astrovirus, & immunochromatographic test & real-time RT-PCR & FTD & Allplex ${ }^{\mathrm{TM}} \mathrm{Gl}$ assay \\
\hline Sapovirus, & real-time RT-PCR & Allplex ${ }^{\mathrm{TM}} \mathrm{Gl}$ assay & FTD & Allplex ${ }^{\mathrm{TM}} \mathrm{Gl}$ assay \\
\hline Norovirus & real-time RT-PCR & Allplex ${ }^{\mathrm{TM}} \mathrm{Gl}$ assay & FTD & Allplex ${ }^{\mathrm{TM}} \mathrm{Gl}$ assay \\
\hline
\end{tabular}

NA not available, FTD Fast-track Diagnostics

${ }^{a}$ Fondazione IRCCS Policlicnico San Matteo, Pavia

${ }^{\mathrm{b}}$ Fondazione Cà Granda Ospedale Maggiore, Policlinico, Milano

rotavirus, adenovirus and sapovirus was performed as previously reported $[20,21]$.

At laboratory B, the Allplex ${ }^{\text {tix }}$ GI one-step real-time RTPCR assay (Seegene Inc., Seoul, South Korea) was used for the diagnosis of the following bacteria: $C$. difficile hypervirulent, $C$. difficile toxin $\mathrm{B}, E$. coli $\mathrm{O} 157$, enterohemorrhagic E. coli (EHEC), enteropathogenic E. coli (EPEC), enterotoxigenic E. coli (ETEC), enteroaggregative E. coli (EAEC), Campylobacter spp., Salmonella spp., Shigella spp./EIEC, Vibrio spp. Y. enterocolitica and Aeromonas spp. Diagnosis of viruses was performed by using the Fast Track Diagnostic ${ }^{\circ}\left(\mathrm{FTD}^{\circ}\right)$ viral gastroenteritis real-time
RT-PCR kit (Fast Track Diagnostics, Luxemburg) in two tube multiplex plus add-on singleplex for the detection of norovirus G1 and G2, astrovirus, rotavirus, adenovirus, sapovirus and the internal control. For parasites, all stool samples were examined microscopically for the detection of ova, cysts and parasites.

\section{Assays for the analysis of discordant results}

Samples showing discordant results between FilmArray and routine methods were further analyzed with an additional assay, where available (Table 1). Discordant bacteria-positive samples were tested by real-time PCR 
with the BD MAX ${ }^{\mathrm{sm}}$ Enteric Bacterial Panel (Becton Dickinson GmbH, Heidelberg, Germany), which detects Salmonella spp., Campylobacter spp. (C. jejuni and C. coli), Shigella spp./EIEC and STEC. Discordant samples positive for virus and parasites were re-tested with a specific real-time RT-PCR or the Allplex ${ }^{\text {ma }}$ GI assay (mix 1, 4) including: Norovirus Gland GII, rotavirus, adenovirus, astrovirus, sapovirus, G. lamblia, E. histolytica, Cryptosporidium spp. and C. cayetanensis (Table 1).

\section{Criteria to resolve discrepant results}

Results were considered true positives if: i) comparator testing and FilmArray ${ }^{\text {na }}$ were both positive (both true positive); ii) comparator testing was positive, FilmArray ${ }^{\mathrm{mu}}$ was negative and discrepancy analysis was positive (initial true positive, FilmArray ${ }^{\text {Tw }}$ false negative); and iii) comparator testing was negative, FilmArray ${ }^{\text {TIx }}$ was positive and discrepancy testing was positive (initial testing false negative, FilmArray ${ }^{\mathrm{Tm}}$ true positive). On the contrary, results were considered true negatives if: i) initial testing and FilmArray ${ }^{\text {Tx }}$ were both negative (both true negative); ii) initial testing was negative, FilmArray ${ }^{\mathrm{Tm}}$ was positive and discrepant testing was negative (initial testing true negative, FilmArray ${ }^{\mathrm{mm}}$ false positive); and iii) initial testing was positive, FilmArray ${ }^{\text {mix }}$ was negative and discrepant testing was negative (initial testing false positive, FilmArray ${ }^{\text {TI }}$ true negative).

\section{Statistical analyses}

The categorical variables are given as numbers and percentages, and the between-group data were compared using contingency table analysis with the $\chi^{2}$ or Fisher's exact test, as appropriate. All of the analyses were twotailed, and carried out using GraphPad Prism version 5 (GraphPad Software Inc., CA, USA); $p$-values of $\leq 0.05$ were considered statistically significant.

\section{Results}

\section{Patient characteristics}

A total of 168 stool samples from as many patients (97 male and 71 female) were included in the study. Of these, 123/168 (73.2\%) were patients with acute gastroenteritis (median age 16 years, range 1 month -88 yrs) while $45 / 168(26.8 \%)$ were children with hemorrhagic diarrhea (median age 3 years, range 2 months - 18 yrs). Among patients with acute gastroenteritis, 102/123 (82.9\%) were hospitalized, $16 / 123(13.0 \%)$ were seen in the emergency department and 5/123 (4.1\%) were outpatients, while all $45(100.0 \%)$ children with hemorrhagic diarrhea were hospitalized.

\section{FilmArray GI panel performance}

Overall, the FilmArray $^{\text {ma }}$ GI panel detected at least one potential pathogen in $92 / 168$ (54.8\%) specimens, while
76/168 (45.2\%) were negative. When considering positivity according to patient categories, we observed that 59 / $123(47.9 \%)$ patients with acute gastroenteritis and 33/45 (73.3\%) patients with hemorragic diarrhea were positive for at least one pathogen.

In 66/92 (71.7\%) of the positive samples, only one pathogen was detected, compared to $14 / 92$ (15.2\%) with two pathogens, 10/92 (10.9\%) with three and 2/92 (2.2\%) with four pathogens. Of the single detections, bacteria were identified in $34 / 66$ (51.5\%) samples, compared to viruses in 24/66 (36.4\%) samples and parasites in 8/66 $(12.1 \%)$ cases. Of the multiple detections, a wide range of combinations was observed: two bacteria and one virus $(7 / 26 ; 26.9 \%)$, three bacteria $(6 / 26 ; 23.1 \%)$, and one bacteria and one virus $(6 / 26 ; 23.1 \%)$, which proved to be the most frequent (data not shown). The most prevalent pathogens were rotavirus 13.9\% (22/168), Campylobacter spp. 10.7\% (18/168), C. difficile 9.5\% (16/168), norovirus 8.9\% (15/168), Salmonella spp. 7.1\% (12/168), EPEC 6.0\% (10/168), STEC 4.2\% (7/168), EAEC 2.9\% (5/168), G. lamblia $2.4 \%$ (4/168), sapovirus $2.4 \%$ (4/168), ETEC $1.8 \%$ (3/168), E. histolytica 1.8\% (3/168), astrovirus $1.8 \%$ (3/168), Shigella/EIEC 1.8\% (3/168), Cryptosporidium $1.2 \%(2 / 168)$, Y. enterocolitica $0.6 \%(1 / 168)$ and adenovirus $0.6 \%(1 / 168)$. No positive samples for $P$. shigelloides, Vibrio spp. and C. cayetanensis were found. The great majority of pathogens were identified in both single and multiple infections, while EPEC (10/168, $6.0 \%)$, ETEC (3/168,1.8\%), Y. enterocolitica $(1 / 168,0.6 \%)$ and adenovirus $(1 / 168,0.6 \%)$ were observed only in coinfections with at least one other pathogen.

As shown in Fig. 1, the pattern of pathogens detected in patients with AGE and hemorragic diarrhea was significantly different. Specifically, $C$. difficile was detected exclusively in patients with AGE (16 vs $0 ; p<0.01$ ), while STEC was detected exclusively in patients with hemorragic diarrhea (6 vs $0 ; p<0.01$ ). Campylobacter spp., Salmonella spp., and E.coli EPEC were more frequently detected in patients with hemorragic diarrhea $(p<0.05)$. To sum up, the overall percent agreement calculated was $73.8 \%$, while the positive and negative percent agreements were $87.5 \%$ and $77.1 \%$, respectively.

\section{FilmArray ${ }^{\mathrm{TM}} \mathrm{Gl}$ vs comparators}

Of the positive FilmArray ${ }^{\mathrm{mat}}$ results $(n=92), 50 / 92$ $(54.3 \%)$ were concordant with the initial results, while 42/92 (45.7\%) results were discordant (Table 2). In 22 out of $42(52.4 \%)$ discordant samples, FilmArray ${ }^{\text {tw }}$ identified at least one additional pathogen (Table 2 samples $\# 1-22$ ). After analysis of the discrepant results, the FilmArray $^{\text {ma }}$ results were confirmed in 17/22 (77.3\%) samples, whereas in $5 / 22(22.7 \%)$ samples, additional pathogens (three rotaviruses, one astroviruses and one sapovirus) identified by FilmArray ${ }^{\mathrm{Tm}}$ were not confirmed. 


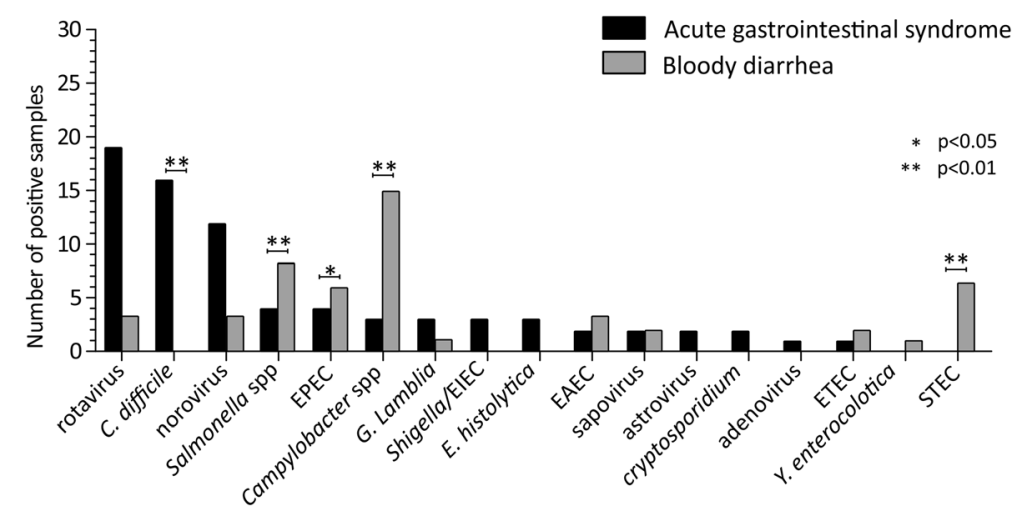

Fig. 1 Distribution of pathogens detected by the FilmArray ${ }^{\mathrm{TM}} \mathrm{Gl}$ panel according to patient category

In addition, five pathogens remained unidentified due to the lack of confirmatory tests for Cryptosporidium, EPEC and EAEC. In 7/42 (16.3\%) discordant samples, FilmArray $^{\text {tix }}$ failed to detect at least one additional pathogen (Table 2, samples \#23-29). In 4/7 (57.1\%) of these samples, FilmArray ${ }^{\mathrm{ma}}$ results were confirmed using the additional methods, while in $1 / 7(14.3 \%)$ sample (\#23) FilmArray $^{\text {tm }}$ results was not confirmed. However, the identified AdV strain was different from those included in the GI panel (F40/41). In 2/7 (28.6\%) cases, no additional test was available to confirm EPEC detection. Finally, in the remaining 13/42 (30.2\%) discordant samples, FilmArray ${ }^{\text {mix }}$ identified at least one additional pathogen but failed to detect at least one other pathogen (Table 2, samples \#3042). In $6 / 13$ (46.2\%) samples, the FilmArray ${ }^{\text {tw }}$ results were confirmed. In $2 / 13(15.4 \%)$ samples, FilmArray ${ }^{\text {ma }}$ results were not confirmed and thus false positive results were observed for one Shigella/Enteroinvasive E. coli and one rotavirus, whereas a false negative result was observed for one adenovirus (typed as AdV-C1). Due to the lack of confirmatory tests for EPEC, EAEC, 4/13 (30.8\%) cases remained unresolved. Finally, in sample \#40, the Allplex $^{\mathrm{Tx}}$ GI assay detected C. difficile, while FilmArray ${ }^{\mathrm{Tw}}$ GI detected Salmonella spp., norovirus and rotavirus. Negative results were obtained using the Allplex ${ }^{\mathrm{Tm}}$ GI as a comparator method for viruses, and the BD $\mathrm{MAX}^{\mathrm{ma}}$ Enteric Bacterial Panel for bacteria. Overall, in 28/42 cases $(66.6 \%)$, the FilmArray ${ }^{\mathrm{Tm}}$ results were confirmed after analysis of discrepant results.

Of the FilmArray ${ }^{\text {mix }}$ negative results $(n=76), 60 / 76$ (78.9\%) were concordant with the initial routine testing results, while discordant results were observed in 16/76 (21.1\%) samples. In 9/16 (56.1\%) discordant samples an adenovirus was detected, compared to a rotavirus in 4/ 16 (25.0\%) samples, C. difficile in 1/16 (6.3\%), an E. histolytica in 1/16 (6.3\%), and an aeromonas in 1/16 (6.3\%) samples. Results from alternative assays are reported in Table 3. All nine samples that were positive for adenovirus were sequenced and in 8/9 cases, the AdV strains (three AdV-A12, three AdV-C1, one AdV-C1 and one $\mathrm{AdV}-\mathrm{C} 2$ ) were different from those included in the GI panel (F40/41). Sequencing failed in one sample and it was therefore excluded from the number of discordant samples. None of the rotavirus-positive samples were confirmed with the additional real-time assay. Finally, the sample that was positive for aeromonas was confirmed as positive but, aeromonas was not included in the FilmArray ${ }^{\text {mi }}$ GI panel and therefore this result could not be considered as truly discordant. Overall, 10/16 $(62.5 \%)$ results were confirmed as truly discordant.

\section{Discussion}

In the present study, the FilmArray ${ }^{\text {mix }}$ GI panel was evaluated in a series of unformed stool samples of patients with GI syndrome and pediatric patients with hemorragic diarrhea. Overall, the FilmArray ${ }^{\text {ma }}$ GI panel identified a pathogen in at least $50 \%$ of analyzed samples. Of the patients with hemorragic diarrhea, the percentage reached $70 \%$. Overall, the detection rate observed in the FilmArray ${ }^{\text {in }}$ analyses ranged from $33.0 \%$ to $62.7 \%$ [14, 18, 22-25]. This wide range of detection frequencies could be attributed to the different patient categories analyzed (adult vs pediatric or outpatient vs inpatient). Other FilmArray ${ }^{\text {Tw }}$ studies analyzing patient populations similar to those included in our study showed a nearly identical positivity rate $[18,23]$. On the contrary, in studies where all or the great majority were patients examined in the outpatient setting, the frequency of detection was lower $(32.9 \%$ and $40.4 \%)$ than studies analyzing hospitalized patients [24, 25]. Our data are also in keeping with a multicenter European study performed with the FilmArray ${ }^{\text {Ti }}$ GI panel aimed at determining the spectrum of possible pathogens involved in acute community-acquired gastroenteritis [22].

Of the positive samples, as expected, the more prevalent pathogens were rotavirus, $C$. difficile, norovirus and Salmonella spp., as also observed by others [14, 22, 26, 27]. The FilmArray $^{\text {ti }}$ GI panel detected a series of diarrheagenic E.coli (DEC) isolates (i.e. EPEC, ETEC, EAEC, EPEC and 


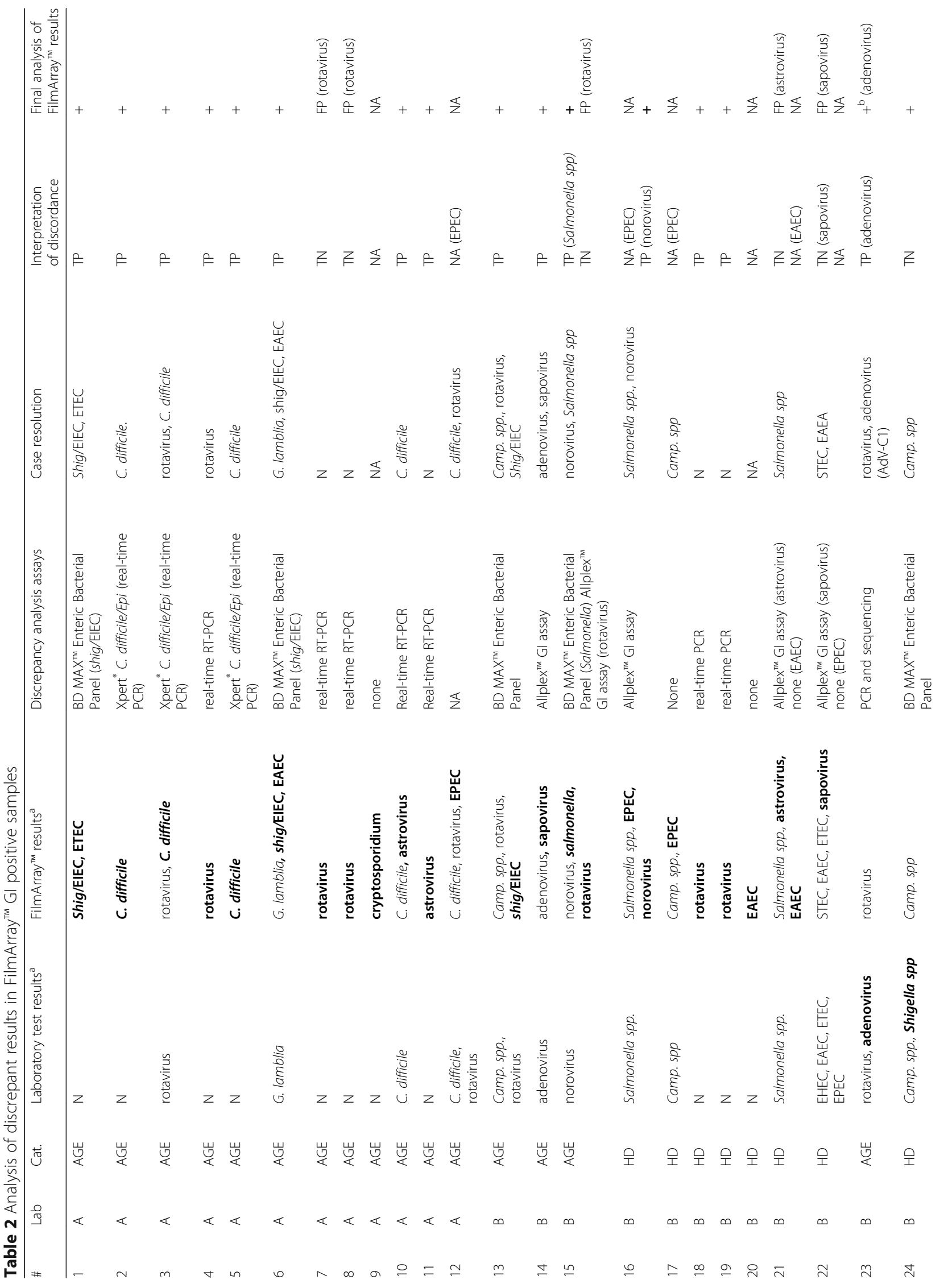




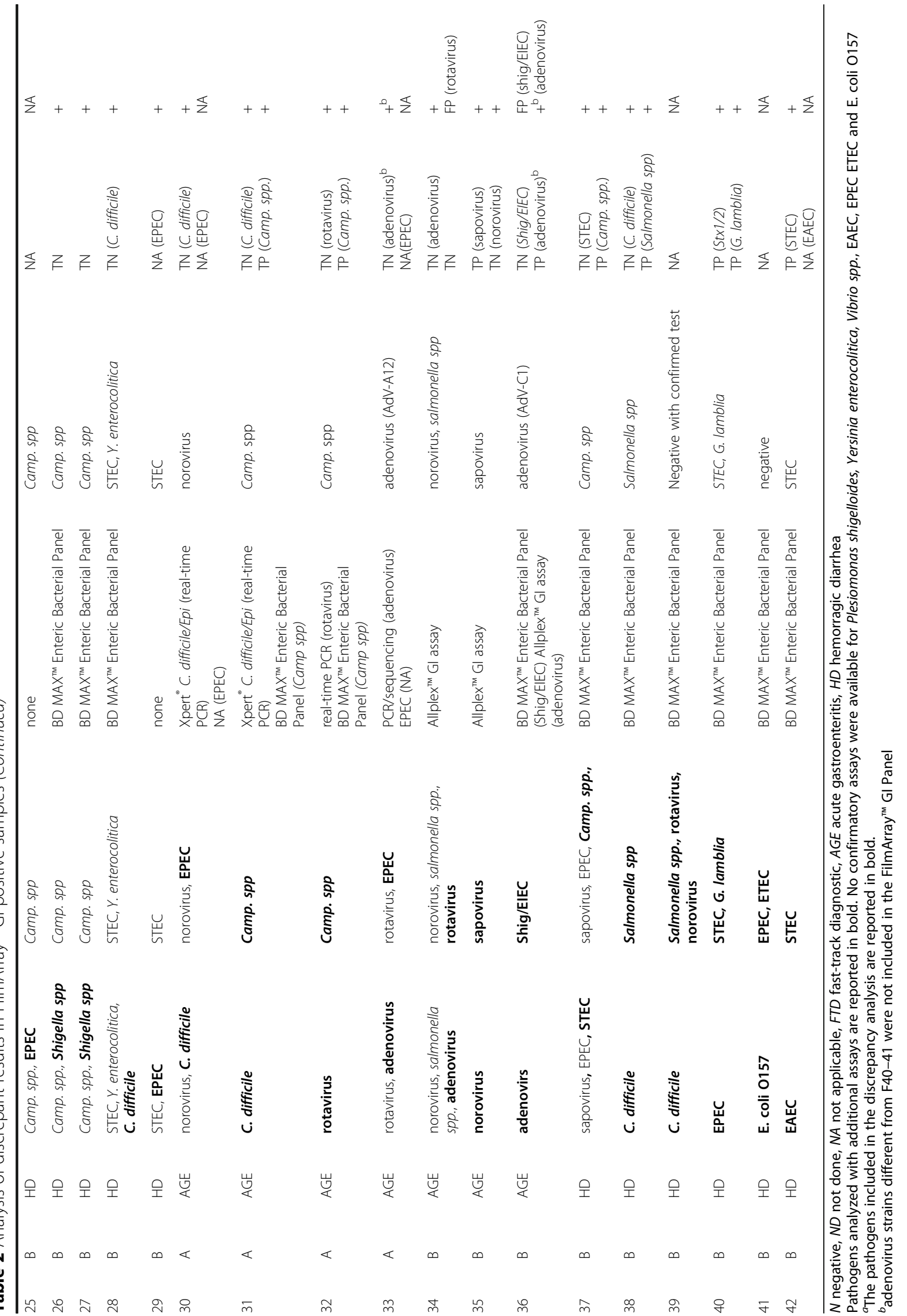


Table 3 Results of discrepancy analysis in FilmArray ${ }^{\mathrm{TM}} \mathrm{Gl}$ negative samples

\begin{tabular}{|c|c|c|c|c|c|c|c|c|}
\hline \# & Lab & Cat. & Laboratory test results & FilmArray $^{\mathrm{TM}}$ results & Discrepancy analysis assays & Case resolution & $\begin{array}{l}\text { Interpretation } \\
\text { of discordance }\end{array}$ & $\begin{array}{l}\text { Final analysis of } \\
\text { FilmArray }{ }^{\mathrm{TM}} \text { results }\end{array}$ \\
\hline 1 & A & AGE & rotavirus & $\mathrm{N}$ & real-time RT-PCR & $\mathrm{N}$ & TN & + \\
\hline 2 & A & AGE & rotavirus & $\mathrm{N}$ & real-time RT-PCR & N & TN & + \\
\hline 3 & A & AGE & C. difficile & $\mathrm{N}$ & $\begin{array}{l}\text { Xpert C. difficile/Epi } \\
\text { (real-time PCR) }\end{array}$ & C. difficile & TP & FN (C. difficile) \\
\hline 4 & A & AGE & adenovirus & N & PCR/sequencing & adenovirus type A12 & $T P^{a}$ & $++^{\mathrm{a}}$ (adenovirus) \\
\hline 5 & A & AGE & E. histolytica & $\mathrm{N}$ & Allplex ${ }^{\mathrm{TM}} \mathrm{Gl}$ assay & E. histolytica & TP & FN (E. histolytica) \\
\hline 6 & A & AGE & rotavirus & $\mathrm{N}$ & real-time RT-PCR & $\mathrm{N}$ & $\mathrm{TN}$ & + \\
\hline 7 & A & AGE & adenovirus & $\mathrm{N}$ & sequencing & adenovirus type A12 & $T P^{a}$ & $+^{\mathrm{a}}$ (adenovirus) \\
\hline 8 & A & AGE & adenovirus & $\mathrm{N}$ & sequencing & adenovirus type $\mathrm{A} 12$ & $T P^{a}$ & $+^{\mathrm{a}}$ (adenovirus) \\
\hline 9 & A & AGE & rotavirus & $\mathrm{N}$ & real-time RT-PCR & $\mathrm{N}$ & $\mathrm{TN}$ & + \\
\hline 10 & B & AGE & adenovirus & N & PCR/sequencing & adenovirus type $C 1^{\mathrm{a}}$ & $T P^{a}$ & $++^{\mathrm{a}}$ (adenovirus) \\
\hline 11 & B & AGE & adenovirus & $\mathrm{N}$ & PCR/sequencing & adenovirus type $C 5^{\mathrm{a}}$ & $T P^{a}$ & $++^{a}$ (adenovirus) \\
\hline 12 & B & AGE & adenovirus & N & PCR/sequencing & P not typed & $T P^{a}$ & NA \\
\hline 13 & B & AGE & adenovirus & $\mathrm{N}$ & PCR/sequencing & adenovirus type $C 1^{\mathrm{a}}$ & $T P^{a}$ & $+{ }^{\mathrm{a}}$ (adenovirus) \\
\hline 14 & B & AGE & adenovirus & N & PCR/sequencing & adenovirus type $C 2^{\mathrm{a}}$ & $\mathrm{TP}^{\mathrm{a}}$ & $++^{\mathrm{a}}$ (adenovirus) \\
\hline 15 & B & AGE & adenovirus & N & PCR/sequencing & adenovirus type $\mathrm{C}^{\mathrm{a}}$ & $T P^{a}$ & $++^{\mathrm{a}}$ (adenovirus) \\
\hline 16 & B & $H D$ & aeromonas $^{a}$ & $\mathrm{~N}$ & Allplex ${ }^{\mathrm{TM}} \mathrm{Gl}$ assay & aeromonas & $T P^{a}$ & NA \\
\hline
\end{tabular}

FTD fast-track diagnostics, TP true positive, $T N$ true negative, $F N$ false negative, NA not applicable, $A G E$ acute gastroenteritis, $H D$ hemorragic diarrhea. No confirmatory assays were available for Plesiomonas shigelloides, Yersinia enterocolitica, Vibrio spp., EAEC, EPEC ETEC and E. coli O157

${ }^{a}$ aromonas and adenovirus types different from F40-41 were not included in the FilmArray ${ }^{\text {TM }}$ Gl Panel

shig/EIEC), which were not included in the routine laboratory procedures for one of the two centers. For many years, these E.coli strains have been considered a leading cause of gastroenteritis only in developing countries [28]. However, there is also a growing number of reports on this problem in developed countries [29, 30]. In addition, DEC types have frequently been observed in co-infections with other enteropathogens with increased illness severity, especially in mixed infections with rotavirus [30]. Nevertheless, in our study, EPEC and ETEC were detected only in coinfections, as also previously observed [25]. Thus, the clinical relevance of these pathogenic E.coli need to be fully elucidated with a case-control study including also asymptomatic patients.

Interesting results were obtained when the distribution of pathogens was analyzed according to the patient category. In patients with acute gastroenteritis, rotavirus and norovirus were the main pathogens detected, along with a significant number of $C$. difficile. In contrast, no patients with hemorragic diarrhea tested positive for $C$. difficile. Indeed, there is very limited published data on C. difficile associated with hemorragic diarrhea and only sporadic cases have been reported [31-33]. On the other hand, in patients with hemorragic diarrhea, Campylobacter spp., Salmonella spp., EPEC and STEC (nonO157) were the main agents detected. Regarding the etiology of HUS, STEC is the most common reported cause of this syndrome in children and this association
(HUS-STEC) is now under epidemiological surveillance in the EU $[34,35]$. Some older reports have described an association between Campylobacter spp. and HUS [36, 37]. More recently, a meta-analysis on the proportion of Campylobacter that develops chronic sequelae (i.e. HUS) was estimated to be lower than $0.01 \%$ [38]. On the contrary, our observations are in keeping with a recent Italian clinical report testing 1251 patients, where Campylobacter spp. and Salmonella spp. were also identified with an unexpectedly high frequency [39]. The authors suggested that the synergic activity played by Campylobacter and Salmonella infection contributed to STEC and EPEC infection.

The data from this evaluation demonstrated that in about $35 \%$ of samples, discordant results were observed when comparing the diagnostic procedures of the two laboratories. In the vast majority, the FilmArray ${ }^{\text {rm }}$ GI panel identified additional pathogens. It is worth noting that an initial increase in the detection of adenovirus was observed in samples under investigation. However, only a few adenovirus-positive samples were confirmed as type F40-41 by molecular typing. Although the performance of the FilmArray ${ }^{\text {ma }}$ GI panel in the identification of adenovirus commonly associated with gastroenteritis (i.e. F40/ 41) proved satisfactory, the FilmArray ${ }^{\text {mix }}$ GI panel missed a series of species $\mathrm{C}$ and $\mathrm{A}$ adenoviruses detected in unformed stools by other methods [40, 41]. The clinical impact of these "atypical" gastroenteric adenoviruses should be further investigated to provide evidence of their clinical 
significance in gastroenteric syndrome. Overall, after additional confirmatory analyses, the proportion of discordant samples decreased to $7.7 \%$. Rotavirus and astrovirus were the most frequently unconfirmed pathogens. The unconfirmed positivity seen in the FilmArray ${ }^{\mathrm{mm}}$ GI panel may be a consequence of non-specific amplification due to the complex nature of stool specimens and high-order multiplex assays [18]. In addition, the discrepant analyses were performed on thawed samples and thus the quality of viral RNA could be affected.

Overall, and in keeping with the findings of previous studies, $27.2 \%$ of the samples were positive for at least two pathogens with a frequent detection incidence of viral and bacterial coinfections [14, 25, 27]. However, the role of coinfections in AGE is still unclear and pathogen associations require further investigation. In this regard, the introduction of quantitative molecular assays could clarify the pathogenetic role or the bystander presence of pathogens associated with GI syndromes. The use of multiplexed PCR such as the FilmArray ${ }^{\text {Tm }}$ GI panel yielded an increased detection rate for GI pathogens, particularly in mixed infections [24]. This finding has opened up the discussion on the clinical interpretation of these multiple infections and their impact on patient management especially in terms of antimicrobial stewardship.

It is important to mention that this study has several limitations, including the lack of a confirmatory test for certain pathogens and the relatively small number of samples. Due to the limited number of positive samples and the different methods used, we were unable to assess sensitivity and specificity for each pathogen included in the FilmArray ${ }^{\text {rat }}$ GI panel. Moreover, the results of this study could be influenced by several factors such as geographic location, season of sampling (DecemberMay) and the patient population analyzed.

\section{Conclusion}

The FilmArray ${ }^{\text {mix }}$ GI panel has proved to be a useful tool in the rapid ( $1 \mathrm{~h}$ turnaround time) diagnosis of gastrointestinal pathogens especially in high-risk patients. Due to the increased detection rate and the wide spectrum of diarrheal pathogens detected, the FilmArray ${ }^{\mathrm{Tm}}$ GI panel has the potential to improve patient management. However, additional studies aimed at evaluating the clinical utility and costeffectiveness of multiplex molecular testing are needed.

\footnotetext{
Abbreviations

AdV: adenovirus; AGE: Acute gastroenteritis; C. cayetanensis: Cyclospora cayetanensis; C. difficile: Clostridium difficile; E. histolytica: Entamoeba histolytica; EAEC: enteroaggregative E. coli; EHEC: enterohemorrhagic E. coli; EIEC: enteroinvasive E. coli; EPEC: enteropathogenic E. coli; ETEC: enterotoxigenic E. coli; FTD: Fast Track Diagnostic.; G. lamblia: Giardia lamblia; GI: Gastrointestinal; HUS: Hemolytic uremic syndrome; P. shigelloides: Plesiomonas shigelloides; STEC: Shiga toxin (Stx)-producing Escherichia coli; Y. enterocolitica: Yersinia enterocolitica;
}

\section{Acknowledgments}

We thank Daniela Sartori for her careful preparation of the manuscript and Laurene Kelly for the revision of the English.

\section{Funding}

This research project was funded by the Ministero della Salute, Fondazione IRCCS Policlinico San Matteo, Ricerca Corrente (grant no. 80682) for the study design, analysis and interpretation of data. It was also supported by bioMérieux (Marcy-l'Etoile, France) who provided supplies and funding for manuscript editing

\section{Availability of data and materials}

All of the data generated and analysed during this study are included in this published article.

\section{Authors' contributions}

FB and GL designed the study. AP, GL, GC, PM supervised laboratory investigations. $G A, M A, M R C, A C, E B$ collected and processed the samples. $A G, M P, E B, A C, P B$ performed the experiments. AP and $G L$ performed the data analysis. AP, FB, GL, wrote the manuscript. All of the authors reviewed and approved the final version of the manuscript.

\section{Competing interests}

The authors have no competing interests to declare.

\section{Consent for publication}

Not applicable.

\section{Ethics approval and consent to participate}

This study was approved by the Institutional Review Board (IRB) of both centres. Informed consent was not required and samples were anonymized, only retaining gender, age and the category of clinical syndromes (acute gastroenteritis or hemorragic diarrhea) according to guidelines on the use of residual biological specimens for scientific purposes in keeping with Italian law (art.13 D.Lgs 196/2003).

\section{Publisher's Note}

Springer Nature remains neutral with regard to jurisdictional claims in published maps and institutional affiliations.

\section{Author details}

${ }^{1}$ Microbiology and Virology Department, Fondazione IRCCS Policlinico San Matteo, Pavia, Italy. ${ }^{2}$ Microbiology and Virology Unit, Fondazione Cà Granda Ospedale Maggiore Policlinico, Milan, Italy. ${ }^{3}$ Center of HUS Control, Prevention and Management, Fondazione Cà Granda Ospedale Maggiore Policlinico, Milan, Italy. ${ }^{4}$ Section of Microbiology, Department of Clinical, Surgical, Diagnostic and Pediatric Sciences, University of Pavia, Pavia, Italy.

Received: 14 January 2017 Accepted: 28 April 2017

Published online: 12 May 2017

\section{References}

1. Clark B, McKendrick M. A review of viral gastroenteritis. Curr Opin Infect Dis. 2004;17:461-9.

2. Ina K, Kusugami K, Ohta M. Bacterial hemorrhagic enterocolitis. J Gastroenterol. 2003:38:111-20

3. Mehta S, Fantry L. Gastrointestinal infections in the immunocompromised host. Curr Opin Gastroenterol. 2005;21:39-43.

4. Katz DE, Taylor DN. Parasitic infections of the gastrointestinal tract. Gastroenterol Clin N Am. 2001;30:797-815.

5. Boyce TG, Swerdlow DL, Griffin PM. Escherichia coli O157:H7 and the hemolytic-uremic syndrome. N Engl J Med. 1995;333:364-8.

6. Frank C, Werber D, Cramer JP, Askar M, Faber M, an der Heiden M, et al. Epidemic profile of Shiga-toxin-producing Escherichia coli 0104:H4 outbreak in Germany. N Engl J Med. 2011;365:1771-80.

7. Chandler WL, Jelacic S, Boster DR, Ciol MA, Williams GD, Watkins SL, et al. Prothrombotic coagulation abnormalities preceding the hemolytic-uremic syndrome. N Engl J Med. 2002;346:23-32.

8. Operario DJ, Houpt E. Defining the causes of diarrhea: novel approaches. Curr Opin Infect Dis. 2011;24(5):464-71. 
9. Kirby A, Gurgel RQ, Dove W, Vieira SC, Cunliffe NA, Cuevas LE. An evaluation of the RIDASCREEN and IDEIA enzyme immunoassays and the RIDAQUICK immunochromatographic test for the detection of norovirus in faecal specimens. J Clin Virol. 2010;49(4):254-7.

10. Platts-Mills JA, Operario DJ, Houpt ER. Molecular diagnosis of diarrhea: current status and future potential. Curr Infect Dis Rep. 2012;14(1):41-6.

11. Reddington K, Tuite N, Minogue E, Barry T. A current overview of commercially available nucleic acid diagnostics approaches to detect and identify human gastroenteritis pathogens. Biomol Detect Quantif. 2014;1(1): 3-7. eCollection 2014

12. Caliendo AM, Gilbert DN, Ginocchio CC, Hanson KE, May L, Quinn TC, et al. Better tests, better care: improved diagnostics for infectious diseases. Clin Infect Dis. 2013;57(Suppl 3):S139-70. doi:10.1093/cid/cit578.

13. Gray J, Coupland LJ. The increasing application of multiplex nucleic acid detection tests to the diagnosis of syndromic infections. Epidemiol Infect. 2014;142:1-11

14. Khare R, Espy MJ, Cebelinski E, Boxrud D, Sloan LM, Cunningham SA, et al. Comparative evaluation of two commercial multiplex panels for detection of gastrointestinal pathogens by use of clinical stool specimens. J Clin Microbiol. 2014;52:3667-73.

15. Liu J, Kabir F, Manneh J, Lertsethtakarn P, Begum S, Gratz J, et al. Development and assessment of molecular diagnostic tests for 15 enteropathogens causing childhood diarrhoea: a multicentre study. Lancet Infect Dis. 2014;14:716-24.

16. Wessels E, Rusman LG, van Bussel MJ, Claas EC. Added value of multiplex Luminex Gastrointestinal Pathogen Panel (XTAG ${ }^{\otimes}$ GPP) testing in the diagnosis of infectious gastroenteritis. Clin Microbiol Infect. 2014;20:0182-7.

17. Buss SN, Leber A, Chapin K, Fey PD, Bankowski MJ, Jones MK, et al. Multicenter evaluation of the BioFire FilmArray gastrointestinal panel for etiologic diagnosis of infectious gastroenteritis. J Clin Microbiol. 2015;53:915-25.

18. Huang RS, Johnson $\mathrm{CL}$, Pritchard $\mathrm{L}$, Hepler $\mathrm{R}$, Ton $\pi$, Dunn JJ. Performance of the Verigene ${ }^{\oplus}$ enteric pathogens test, Biofire FilmArray ${ }^{\mathrm{TM}}$ gastrointestinal panel and Luminex XTAG ${ }^{\circledR}$ gastrointestinal pathogen panel for detection of common enteric pathogens. Diagn Microbiol Infect Dis. 2016;86(4):336-9.

19. Drancourt M, Michel-Lepage A, Boyer S, Raoult D. The Point-of-care laboratory in clinical microbiology. Clin Microbiol Rev. 2016;29(3):429-47. doi:10.1128/CMR.00090-15. Review

20. Rovida F, Campanini G, Piralla A, Adzasehoun KM, Sarasini A, Baldanti F. Molecular detection of gastrointestinal viral infections in hospitalized patients. Diagn Microbiol Infect Dis. 2013;77:231-5.

21. Rovida F, Campanini G, Sarasini A, Adzasehoun KM, Piralla A, Baldanti F. Comparison of immunologic and molecular assays for the diagnosis of gastrointestinal viral infections. Diagn Microbiol Infect Dis. 2013;75:110-1.

22. Spina A, Kerr KG, Cormican M, Barbut F, Eigentler A, Zerva L, et al. Clin Microbiol Infect. 2015;21:719-28.

23. Stockmann C, Pavia AT, Graham B, Vaughn M, Crisp R, Poritz MA, et al. Detection of 23 gastrointestinal pathogens among children who present with diarrhea. J Pediatric Infect Dis Soc. 2016; [Epub ahead of print]

24. Murphy CN, Fowler RC, Iwen PC, Fey PD. Evaluation of the BioFire FilmArray ${ }^{\circledast}$ gastrointestinal panel in a midwestern academic hospital. Eur J Clin Microbiol Infect Dis. 2016;12 [Epub ahead of print]

25. Park S, Hitchcock MM, Gomez CA, Banaei N. Is follow-up testing with FilmArray gastrointestinal multiplex PCR panel necessary? J Clin Microbiol. 2017;

26. Vocale C, Rimoldi SG, Pagani C, Grande R, Pedna F, Arghittu M, et al. Comparative evaluation of the new XTAG GPP multiplex assay in the laboratory diagnosis of acute gastroenteritis. Clinical assessment and potential application from a multicentre Italian study. Int J Infect Dis. 2015;34:33-7.

27. Tran A, Talmud D, Lejeune B, Jovenin N, Renois F, Payan C, et al. Prevalence of rotavirus, adenovirus, norovirus, and astrovirus infections and coinfections among hospitalized children in northern France. J Clin Microbiol. 2010;48: 1943-6.

28. Gomes TA, Rassi V, MacDonald KL, Ramos SR, Trabulsi LR, Vieira MA, et al. Enteropathogens associated with acute diarrheal disease in urban infants in São Paulo, Brazil. J Infect Dis. 1991;164:331-7.

29. Foster MA, labal J, Zhang C, McHenry R, Cleveland BE, Romero-Herazo Y, et al. Enteropathogenic and enteroaggregative E. coli in stools of children with acute gastroenteritis in Davidson County, Tennessee. Diagn Microbiol Infect Dis. 2015;83:319-24.

30. Tobias J, Kassem E, Rubinstein U, Bialik A, Vutukuru SR, Navaro A, et al. Involvement of main diarrheagenic Escherichia coli, with emphasis on enteroaggregative E. coli, in severe non-epidemic pediatric diarrhea in a high-income country. BMC Infect Dis. 2015;15:79.
31. Alvarado AS, Brodsky SV, Nadasdy T, Singh N. Hemolytic uremic syndrome associated with Clostridium difficile infection. Clin Nephrol. 2014;81:302-6.

32. Butani L. Hemolytic uremic syndrome associated with Clostridium difficile colitis. Pediatr Nephrol. 2004;19:1430.

33. Keshtkar-Jahromi M, Mohebtash M. Hemolytic uremic syndrome and Clostridium difficile colitis. J Community Hosp Intern Med Perspect. 2012;2:3.

34. Jenssen GR, Hovland E, Bjerre A, Bangstad HJ, Nygard K, Vold L. Incidence and etiology of hemolytic-uremic syndrome in children in Norway, 19992008 - a retrospective study of hospital records to assess the sensitivity of surveillance. BMC Infect Dis. 2014;14:265.

35. Kaplan BS, Meyers KE, Schulman SL. The pathogenesis and treatment of hemolytic uremic syndrome. J Am Soc Nephrol. 1998;9:1126-33.

36. Chamovitz BN, Hartstein Al, Alexander SR, Terry AB, Short P, Katon R Campylobacter jejuni-associated hemolytic-uremic syndrome in a mother and daughter. Pediatrics. 1993;71:253-6.

37. Delans RJ, Biuso JD, Saba SR, Ramirez G. Hemolytic uremic syndrome after Campylobacter-induced diarrhea in an adult. Arch Intern Med. 1984;144:1074-6.

38. Keithlin J, Sargeant J, Thomas MK, Fazil A. Systematic review and metaanalysis of the proportion of Campylobacter cases that develop chronic sequelae. BMC Public Health. 2014;14:1203.

39. Ardissino G, Possenti I, Salardi S, Tel F, Colombo E, Testa S, et al. Coinfection in children with bloody diarrhea caused by Shiga toxin-producing Escherichia coli: data of the North Italian HUS Network. J Pediatr Gastroenterol Nutr. 2014:59:218-20.

40. Li L, Phan TG, Nguyen TA, Kim KS, Seo JK, Shimizu H, et al. Molecular epidemiology of adenovirus infection among pediatric population with diarrhea in Asia. Microbiol Immunol. 2005;49:121-8.

41. Moyo SJ, Hanevik K, Blomberg B, Kommedal O, Nordbø SA, Maselle S, et al. 2014. Prevalence and molecular characterisation of human adenovirus in diarrhoeic children in Tanzania; a case control study BMC Infect Dis. 2014;14:666.

\section{Submit your next manuscript to BioMed Central and we will help you at every step:}

- We accept pre-submission inquiries

- Our selector tool helps you to find the most relevant journal

- We provide round the clock customer support

- Convenient online submission

- Thorough peer review

- Inclusion in PubMed and all major indexing services

- Maximum visibility for your research

Submit your manuscript at www.biomedcentral.com/submit
) Biomed Central 